\title{
PROCEEDINGS From
}

\section{SEMANTICS \\ AND \\ LINGUISTIC \\ THEORY}

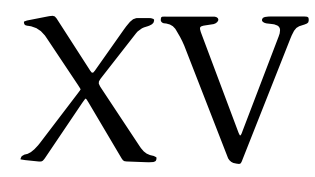

EDITED BY

EfFi GeORGala AND JonAthan Howell

CORNELl UNIVERSITY

ITHACA 2005 


\section{ACKNOWLEDGMENTS}

This proceedings contains papers from the fifteenth conference in Semantics and Linguistic Theory, March 25-27, 2005, at UCLA (University of Caifomia, Los Angeles). We thank the conference organizers and the reviewers who rated and commented on the many abstracts submitted to the conference. Thanks especially to the authors, whose patient assistance and swift responses have greatly aided the editing process. Unfortunately, the papers presented by RicardoEtxepare and Scott Soames were not available for publication in this volume.

Finally, thanks to Dorit Abusch and Mats Rooth for their guidance, and to Abby Cohn, Sheila Haddad, Wayne Harbert, Angie Tinti, Robert Young and the Field of Linguistics at Cornell University for making the publication possible.

Effi Georgala and Jonathan Howell

Editors

December 2005 